\title{
The Role of Adults on Children Language Acquisition
}

\author{
Meiyanti Nurchaerani ${ }^{1}$, Yessy Nurkita Sari ${ }^{2}$, Haryati ${ }^{3}$, Syahiid Hidayatullah Rizkyka \\ Hartadhi ${ }^{4}$ \\ ${ }^{1}$ Universitas Esa Unggul, Jakarta \\ 2, 3 Universitas Putra Indonesia, Cianjur \\ ${ }^{4}$ Universitas Padjadjaran, Bandung \\ 1meiyanti.nurchaerani@esaunggul.ac.id, ${ }^{2}$ yessyns4900@gmail.com, 3 haryatihry237@gmail.com, \\ 4syahiid13@gmail.com
}

\begin{abstract}
This study aims to notice at the language skills of children from birth to the age of eight years based on the role of adults. The research subject is a boy whom will be known as $X$, eight years old. This research just focused on $X$ 's development of language. Furthermore, children's language acquisition can be categorized into phonology, grammar, semantics, and pragmatics. In collecting data, the authors interviewed one of a friend of the author, named $Y$. The results of this study indicate the process of language development in children that can be influenced by the role of adults. When the role of adults towards children is not appropriate, then children will experience postpones in language acquisition or postpones in language development in children.
\end{abstract}

Keywords: the role of adults, psycholinguistics, and language acquisition.

\section{INTRODUCTION}

Children are a gift from God where they are born from a marriage between a man and a woman. According to psychology, a child is a development that starts from infancy until the age of five or six years. At these times, children are usually very fond of learning something new, such as what they see, feel, or hear, one example they will be interested in a language. When they are babies, adults usually start talking to their babies, so that babies will indirectly respond to adults. Language is an ability that humans have to communicate with other humans using signs, such as words and gestures. While language is an expression of one's thought by means of name of object and speech which is a reflection of one's ideas. Generally, language was used for sharing information or received information from other or by other.

Although, language is a tool to express something, but if adults to children it is a different thing. According to Allan Garnham, as cited in Nordquist (2019), 
psycholinguistics is the study of the mental mechanisms that make it possible for people to use language. Cited more in Nordquist (2019), Alan Garnham states that psycholinguistics is a scientific discipline whose goal is a coherent theory of the way in which language is produced and understood. So, Psycholinguistics is the study about language and speech that concerned with mental aspects. And it is concerned with ways how language is represented and processed in the brain. Language acquisition in children language development related with their brain, because they're still learning about language. Of course, talking to children must also have conditions, such as adults having to sort out the appropriate words for teaching to children, holding back their emotions when the children start to fuss, as well as holding back the feeling of wanting to say harsh words. Also, adults should monitor the development of the language children are learning, because one of the most important children developments is the acquisition of the language.

On this day, the development of period has had a big influence on the life of a child. One of them is the parenting manner taught by adults. A phenomenon that usually occurs today is that parents entrust their children to caregiver. Indeed, this is not wrong, however, because of their busy lives, parents rarely communicate with their children. Their children tend to be more accustomed to their caregiver than their own parents. Parents must also be observant if they want to choose a caregiver, whether to push the child in a negative or positive lifestyle.

Then, there are other factors such as the child's biological and mental condition, nutrition, and the patience of adults for the education of the child which can also affect the child's language skills. This study aims to develop children's language from birth to 8 years of age, especially for the research subject, $X$. This study aims to determine the acquisition acquired from adults when learning languages.

\section{METHODS}

This research used qualitative descriptive method, where this type of method indicates the data results as they are without any manipulation or other processes. Cited in Muchta (2019), Creswell defined qualitative research as an inquiry process 
of understanding based on distinct methodological traditions of inquiry that explore a social or human problem. The researcher builds a complex, holistic picture, analyzes word, report detailed views of information, and conducts the study in a natural setting.

Here, the author tries to understand the phenomenon of what is experienced by the research subject, for example, behavior, perception, and others by way of description in the form of words and language.

\section{RESULTS AND DISCUSSION}

Psycholinguistics is the study about language and speech that concerned with mental aspects. And it is concerned with ways how language is represented and processed in the brain. Psycholinguistics can be used to verify language acquisition in children. Usually, developing children's minds will acquire their first language or mother tongue in the first years of their life, and this process develops until about five years of age.

$X$, the research subject has learned language from birth. His sister, $Y$ has taught him two languages - decent Sundanese or Sunda Lemes, and Indonesia. Since birth, $X$ 's parents have always talked to him. At the age of six months, $X$ uttered his first words, namely 'ba' refers to bapak (English 'dad') and 'mam' refers to mama (English 'mom'). The ability at the phonological level, $X$ began to develop at the age of six months. The dominant consonant sounds managed by $\mathrm{X}$ are $\mathrm{m}$ [ma] and $\mathrm{b}$ [ba] sounds. The syllables [ma] and [ba] usually mean the words [mama] and [bapak]. Because he is not yet fluent in speaking, $X$ usually cries if he asks for something or laughs when playing with him.

After being 1 year old, $X$ started to speak but it was not very fluent. He started to ask anything and obeyed what the adults said. One day, $\mathrm{Y}$ accidentally calls 'cat' as 'monkey' because she is upset. Then at another time, $\mathrm{Y}$ asked $\mathrm{X}$ to talk:

Yuni : : "Dek, tinggal aya onyet," sambil menunjuk kucing. 
"Look, there is a monkey," pointing at the cat.

Alfarizi : :Onyett," melihat si kucing.

"Monkey," looking at the cat.

She regretted it after called the cat as monkey, because everytime $X$ saw a cat, he always said that is a monkey. Luckily, $\mathrm{Y}$ had told him that it was wrong. In this point, the adult's role is very important. Basically, when adults want to say something, especially around children, adults should have to be careful of what adults want to say. Even in the conversation above, according to the author, it is fatal, especially when adults saying something rude.

At the age of 2-3 years, $X$ lived with his grandmother. His grandmother taught him Sundanese or Sunda Lemes and as usual, two years old is not very fluent but already understands what his grandmother taught him. Then, at the age of three years old, $X$ began to speak fluently and began to nag. Because it is already fluent, then $X$ were taught about polite and correct language (pragmatics), then how to express something through words (semantics), and how to position the predicate, subject, and object in one sentence (grammar). Pragmatics is how language is used in communication. Pragmatics is defined relative to a defined purely as a property of expressions in a given language, in abstraction from particular situations, speakers, or hearers (Leech, 1983). While according to Nick Riemer, as cited in Nordquist (2020), the job of semantics is to study the basic, literal meanings of words as considered principally as parts of a language system, whereas pragmatics concentrates on the ways in which these basic meanings are used in practice, including such topics as the ways in which different expressions are assigned referents in different contexts, and the differing (ironic, metaphorical, etc.) uses to which language is put.

At five years old, $X$, he began to utter bad word, it is because of environmental factor and his friends. From this, his friends said harsh words must be because they heard what the adults were saying. They are accustomed to hearing something harsh from adults, because of this thing, these children use harsh words as a daily basis. 
This is also what makes $X$ utters something bad. For example, he once said the word 'maneh' [English 'you'], but it is bad word in Sundanese. Because he said that word, $\mathrm{Y}$ accidentally pinched his mouth. The role of an adult here is not easy, especially it takes extra patience to educate children.

From 6-7 years old, $X$ is already fluent in speaking, it's just that he is still slurred. Slurred is normal and will usually leave as he learns and practices how to pronouncing letters. And by the time he was eight years old, the slurred was gone.

\section{CONCLUSIONS}

Based on the research above, it can be concluded that the process of a child's language development is strongly influenced by the role of adults when teaching children to speak. When adults, especially parents, rarely asked their children to talk, it can affect children's language development, such as delayed speaking. Different with adults around $X$, mainly his parents, they were always talking to him even at the time he was born. Therefore, at the age of six months, $\mathrm{X}$ was able to say his first word. Although $X$ had used harsh words, $Y$ told him that it was not right, even by pinched him.

\section{REFERENCES}

Leech, G. N. (1983). Principles of Pragmatics (1st ed.). Routledge.

Muchta, A. (2019, June 17). 9 Definisi Metode Penelitian Kualitatif Menurut Para Ahli. https://www.autoexpose.org/2019/06/definisi-metode-penelitiankualitatif.html

Nordquist, R. (2019, September 6). What Is Psycholinguistics? https://www.thoughtco.com/psycholinguistics-1691700

Nordquist, R. (2020, May 13). An Introduction to Semantics. https://www.thoughtco.com/semantics-linguistics-1692080 